Meaning and Moral Order 
This page intentionally left blank 


\section{Meaning and Moral Order}

Explorations in Cultural Analysis

\section{Robert Wuthnow}


This book is a print-on-demand volume. It is manufactured using toner in place of ink. Type and images may be less sharp than the same material seen in traditionally printed University of California Press editions.

University of California Press

Berkeley and Los Angeles, California

University of California Press, Ltd.

London, England

(C) 1987 by

The Regents of the University of California

First Paperback Printing 1989

\section{Library of Congress Cataloging-in-Publication Data}

Wuthnow, Robert.

Meaning and moral order.

Bibliography: $\mathrm{p}$.

Includes index.

1. Religion and sociology. 2. Sociology.

3. Social ethics. 4. Ideology. 5. Culture.

I. Title.

BL60.W87 $1987 \quad 306 \quad 86-13668$

ISBN 0-520-06621-9 (alk. paper)

Printed in the United States of America

The paper used in this publication meets the minimum requirements of ANSI/NISO Z39.48-1992 (R 1997)

(Permanence of Paper). $@$ 
For Robert N. Bellah and Charles Y. Glock 
This page intentionally left blank 